\title{
Evaluation of chickpea genotypes against Fusarium wilt for resistant sources
}

\author{
S.C. DUBEY ${ }^{*}$, BIRENDRA SINGH ${ }^{2}$ and N. SRINIVASA ${ }^{2}$ \\ ${ }^{1}$ Division of Plant Quarantine, ICAR-National Bureau of Plant Genetic Resources, New Delhi 110 012, India \\ ${ }^{2}$ Division of Plant Pathology, ICAR-Indian Agricultural Research Institute, New Delhi, 110 012, India
}

Received: 20 February 2017/ Accepted: 17 May 2017/ Published online: 25 May 2017 CIndian Phytopathological Society 2017

\begin{abstract}
Wilt caused by Fusarium oxysporum f. sp. ciceris is an important yield limiting disease of chickpea. Cultivation of resistant cultivars is an economical management option for the disease. Six hundred sixty eight genotypes of chickpea were screened against $F$. oxysporum f. sp. ciceris in sick field for three years from 2013-14 to 2015-16. The genotypes SCGP-WR 28, H 10-05, GL 10023, IPC 2006-77 and CSJK 72 were found to be resistant and the genotypes H 09-70, H 08-25, H 10-16, DCP 92-3, GNG 1936 and Pusa 212 were moderately resistant. The remaining genotypes showed susceptible reaction against the disease. These genotypes could be cultivated as such or used as resistance source in breeding programme.
\end{abstract}

Keywords: Cicer arietinum, Fusarium wilt, genotypes, screening

Chickpea (Cicer arietinum L.) is an important pulse crop widely cultivated in India as well as in other tropical, subtropical and temperate regions of the world. Susceptibility to diseases is one of the major causes for low productivity of chickpea. Among the diseases affecting chickpea, wilt caused by Fusarium oxysporum f. sp. ciceris (Padwick) Matuo and K. Sato causes severe losses to chickpea production throughout the world (Gupta el al., 2009). In India, it is prevalent in all chickpea growing states (Dubey et al., 2010) and causes an annual yield loss of 10-20 per cent (Vishwadhar and Chaudhary,
2001), but the losses varies depending on the stages of the crop infected and severity of the disease (Dubey, 2016). The disease is soil and internally seed borne (Haware et al., 1978). For such diseases, use of resistant varieties is one of the most practical and cost effective management strategies. Therefore, evaluation of chickpea genotypes for Fusarium wilt resistant is highly imperative to ensure the availability of resistant varieties.

Wilt of chickpea is characterized by drooping of leaves, change of colour to a dull green and uneven shrinkage at the collar region. The disease can affect

Table 1. Reaction of genotypes of chickpea during 2013 to 2016 against Fusarium wilt

\begin{tabular}{|c|c|c|c|c|c|c|c|}
\hline \multirow[t]{2}{*}{ Genotypes } & \multirow[t]{2}{*}{ Type } & \multicolumn{3}{|c|}{ Wilt incidence (\%) } & \multirow[t]{2}{*}{ Mean } & \multirow[t]{2}{*}{ Reaction } & \multirow{2}{*}{$\begin{array}{c}\text { ICAR-NBPGR } \\
\text { Gene Bank Acc. No. }\end{array}$} \\
\hline & & 2013-14 & $2014-15$ & $2015-16$ & & & \\
\hline SCGP-WR 28 & Desi & 4.3 & 7.0 & 8.0 & 6.4 & Resistant & IC-621781 \\
\hline H 10-05 & Desi & 5.8 & 8.5 & 9.2 & 7.8 & Resistant & IC-621782 \\
\hline GL 10023 & Desi & 9.6 & 8.4 & 7.5 & 8.5 & Resistant & IC-621783 \\
\hline IPC 2006-77 & Desi & 9.0 & 8.5 & 10.0 & 9.2 & Resistant & IC-616402 \\
\hline CCJK 72 & Kabuli & 8.1 & 10.0 & 9.7 & 9.3 & Resistant & IC-621784 \\
\hline H 09-70 & Desi & 8.7 & 14.0 & 16.2 & 13.0 & Moderately Resistant & IC-621785 \\
\hline H 08-25 & Desi & 9.3 & 16.2 & 15.2 & 13.7 & Moderately Resistant & IC-621786 \\
\hline H 10-16 & Desi & 10.9 & 18.5 & 16.5 & 15.3 & Moderately Resistant & IC-621787 \\
\hline DCP 92-3 & Desi & 13.1 & 14.6 & 15.5 & 14.4 & Moderately Resistant & IC-405199 \\
\hline GNG 1936 & Desi & 15.7 & 16.0 & 19.5 & 17.1 & Moderately Resistant & IC-621788 \\
\hline Pusa 212 & Desi & 19.6 & 18.5 & 17.4 & 18.5 & Moderately Resistant & IC-405203 \\
\hline $\begin{array}{l}\text { JG } 62 \\
\text { (Susceptible check) }\end{array}$ & Desi & 100.0 & 100.0 & 98.5 & 99.5 & Highly Susceptible & - \\
\hline
\end{tabular}

${ }^{*}$ Corresponding author: scdube2002@yahoo.co.in 
the crop at any stage of growth. Wilted plants when cut transversely in the collar region or splitted vertically from the collar region downwards, brown or black discolouration of both pith and xylem can be seen. Wilted plants did not show external signs of root- rot (Dubey and Singh, 2016). Six hundred and sixty eight genotypes of chickpea were screened in wilt sick field at the Research Farm of the Indian Agricultural Research Institute, New Delhi during winter season of three consecutive years 2013-14, 2014-15 and 2015-16. Each genotype was sown in $5 \mathrm{~m}$ long, two rows in two replications in the first week of November. Single row of highly susceptible cultivar JG 62 as check was also sown after two-test genotype. Wilt incidence was recorded at fortnight interval after germination up to the maturity of the crop. The genotypes were graded for their resistant based on the percent wilt incidence (Dubey et al., 2010).

Out of 668 genotypes evaluated, 5 genotypes viz., SCGP-WR 28, H 10-05, GL 10023, IPC 2006-77 and CSJK 72 showed < 10 per cent wilt incidence were graded as resistant. Six genotypes viz., H 09-70, $\mathrm{H}$ 0825, H 10-16, DCP 92-3, GNG 1936 and Pusa 212 were found to be moderately resistant (Table 1). The rest of the genotypes were found susceptible to highly susceptible against wilt disease. The seeds of resistant and moderately resistant genotypes have been deposited in the National Gene Bank, NBPGR, New Delhi and obtained accession number (Table 1). These genotypes could be utilized further in cultivation as well as in resistance breeding programme of chickpea.

\section{REFERENCES}

Dubey SC (2016). Race profiling, genetic diversity, diagnostics and management of Fusarium oxysporum f. sp. ciceris causing wilt in chickpea. Indian Phytopath. 69: 210-217.

Dubey SC and Singh Birendra (2016). Diseases of pulse crops. In: Diseases of field crops and their management. (Dubey SC, Aggarwal R., Patro TSSK and Sharma P eds.). Today \& Tomorrows Printers and Publishers, New Delhi 373-444 pp.

Dubey SC, Singh SR and Singh Birendra (2010). Morphological and pathogenic variability of Indian isolates of Fusarium oxysporum f. sp. ciceris causing chickpea wilt. Arch. Phytopathol. Plant Prot. 43: 174-189.

Gupta S, Chakraborti D, Rangi RK, Basu D and Das S (2009). A molecular insight into the early events of chickpea (Cicer arietinum) and Fusarium oxysporum f. sp. ciceri (race 1) interaction through cDNA-AFLP analysis. Phytopathology 99: $1245-1257$.

Haware MP, Nene YL and Rajeshwari R (1978). Eradication of Fusarium oxysporum f. sp. ciceri transmitted in chickpea seed. Phytopathology 68: 1364-1367.

Vishwadhar and Chaudhary RG (2001). Disease resistance in pulse crop. Current status and future approaches. In: The role of resistance in intensive agriculture (Nagarajan $\mathrm{S}$ and Singh DP eds.) Kalyani Publisher, New Delhi 144-157pp. 